Robinson, Matthew B. (1998). Burglary Revictimization: The time period of heightened risk for repeat burglary victimization, British Journal of Criminology, 38, 1: 78-87.

Original published by Oxford and available at: http://0-bjc.oxfordjournals.org

(ISSN: 0007-0955)

\title{
Burglary Revictimization: The Time Period of Heightened Risk
}

\author{
Matthew B. Robinson
}

\begin{abstract}
Residents can expect and prepare for burglary if they are prone to victimization. The risk for a repeat action of burglary appears immediately after the initial offense. Crime records indicate $25 \%$ of repeat burglaries occur within one week of the initial crime and $51 \%$ occur within 1 month. This information can facilitate temporary preventive measures by residents and law enforcement officials.
\end{abstract}

\section{ARTICLE}

Research into the phenomenon of revictimization has consistently demonstrated that a very small proportion of all people and places suffer from a disproportionate amount of victimizations. Whenever victims of both personal and household crimes are likely to be victimized again, victimization is most likely to occur a very short time after the initial offences. Findings from this study confirm these ideas. Only 1.2 per cent of all residences in the jurisdiction studied suffered from 29 per cent of all burglaries reported to the police between the years 1992 and 1994. Furthermore, 25 per cent of the burglary revictimizations occurred within one week of the initial offences, while 51 per cent occurred within one month. These findings are discussed in the context of prevention of burglary revictimization.

Revictimization 'occurs when the same person or place suffers from more than one criminal incident over a specified period of time'(Ross 1994:1). When people or places are revictimized, 'there (are) more crime than victims, so incidence is higher than 
prevalence, and concentration is ... always greater than one' (Farrell and Pease 1993: 5). For example, if residential burglary revictimization was occurring in a given area, one would expect to find more burglaries reported to police than burglared residences. In other words, some targets would have been victimized by more than one burglary. Such places suffering from criminal revictimization can be thought of as 'hot spots' (Sherman et al. 1989). Hot spots can also exist when many one-time victims reside in a limited geographical area (Block and Block 1995: 147; Buerger et al. 1995; Sherman 1995: 35). For the purposes of this paper, a hot spot is a place (e.g., a residential dwelling) where criminal revictimization has occurred. This definition is consistent with the well-known hot spot research done by Sherman et al. (1989: 37), who analysed spatial data on 323,979 calls to the police over an estimated 115,000 addresses and intersections in Minneapolis in one year and found that 'a majority (60 per cent) of all addresses generated at least one call over the course of the year, but almost half of those addresses produced one call and no more'. Thus, many addresses produced more than one call to police. For example, all 15,961 calls to police for burglary in a year in Minneapolis came from only 11 per cent of all street addresses (hot spots). More strikingly, 50 per cent of all calls came from only 3 per cent of places.

It is now treated in the literature as common knowledge that very small segments of the population suffer from disproportionate amounts of criminal victimization, and that this phenomenon is not due to simple chance alone (Farrell 1994: 470; Polvi et al. 1990: 8, 1991: 411). While Sparks (1981) was one of the first in modern revictimization literature to suggest that previous crime victims were disproportionately likely to become victims again at a later time, further empirical support has been generated for the phenomenon of revictimization (Burquest et al. 1992; Farrell and Pease 1993; Farrell 1992, 1994; Feinberg 1980; Forrester et al. 1988a, 1988b; Forrester et al. 1990; Germ 1988; Gottfredson 1984; Hindeland et al. 1978; Hope 1982; Hough 1986; Johnson et al. 1973; Jones et al. 1986; Mayhew et al. 1993; Nelson 1980; Pease 1991, 1992; Polvi et al. 1990, 1991; Reiss 1980; Sampson 1991; Sampson and Phillips 1992; Shapland et al. 1991; Shepherd 1990; Sherman et al. 1989; Skogan 1990a, 1990b; Sparks 1981; Sparks et al. 1977; Tilley 1993; Trickett et al. 1992; Ziegenhagen 1976). With regard to the crime of burglary, research (Forrester et al. 1990; Polvi et al. 1990, 1991) demonstrates that revictimization is concentrated on few residences and is less likely to occur with the passage of time. Polvi et al. $(1990,1991)$ found that previously burgled dwellings in Saskatoon in 1987 were almost four times more likely than non-burglared residences to be burgled again, and 50 per cent of revictimization occurred within seven days of the initial offences. The results of the growing body of research leaves one with the sense that revictimization is a reality across all crime types, all locations, and all periods of study (Farrell et al. 1995: 501). 
In fact, criminal revictimization may account for a large share of all criminal victimizations. If this is true, then preventing criminal revictimizations may mean preventing a large percentage of all criminal victimizations (Farrell 1994: 469; National Board for Crime Prevention 1994: 2). For example, one-half of all victimized respondents of the 1992 British Crime Survey were repeat victims. They suffered from 81 per cent of all reported crimes. Furthermore, 4 per cent of those who suffered from criminal victimizations more than once were victimized four or more times in a year, and accounted for 44 per cent of all reported crimes (Farrell and Pease 1993).

As discussed by Farrell (1994), if we can determine who it is that is most likely to be victimized by crime, particularly those who will likely suffer from more than one victimization, then we may be able to prevent criminal victimizations more efficiently. However, Farrell counsels us that 'more energy and resources' must be directed at the phenomenon of revictimization in order for this to occur. This paper is one attempt at answering the call to further revictimization research.

\section{Why Does Revictimization Occur?}

Although the purpose of this paper is to examine the time period of heightened risk for burglary revictimization, a brief review of some explanations for the phenomenon may be in order. To prevent criminal revictimization, it might be wise to understand why it happens. Sparks (1981: 772-8) was one of the first modem theorists to hypothesize about the causes of revictimization. He discussed many concepts that he believed were relevant, including victim precipitation, vulnerability, opportunity, target attractiveness, impunity and lifestyle. He wrote that a multiple victim may 'facilitate its commission--by deliberately, recklessly, or negligently placing himself at special risk ... Anyone who fails to take reasonable precautions against crime may be said to have facilitated a crime against him'. Also, some people 'because of their attributes, usual behaviour, or their place in a social system, may be very vulnerable' to revictimization. Vulnerability factors may be related to status (e.g., sex, class), or may be ecological (e.g., living in a bad neighbourhood). The likelihood of criminal revictimization is said to be highest for these groups who are most vulnerable in society (Pease 1992).

Other explanations for the phenomenon of revictimization include the routine activities approach of Cohen and Felson (1979) and the lifestyle-exposure approach of Hindelang 
et al. (1978), which emphasize the role of the lifestyle of offenders and victims and how they influence opportunities for criminal revictimization through the creation of attractive or suitable targets (Miethe et al. 1987). Of course, part of what determines high or low rates of revictimization are high or low rates of criminal victimization (Sherman et al. 1989: 43). Sparks (1981: 778) wrote that criminal victimization and revictimization may be a matter of chance alone and 'absolutely unrelated to attributes or behaviour' of the victim. However, in a study by Forrester et al. (1988a), rates of repeat burglary victimization were higher than would have normally been expected given a random distribution of burglary.

As discussed by Farrell et al. (1995: 386), the main question yet to be definitively answered about why criminal revictimization occurs is whether it is due to enduring characteristics about targets which make them attractive or suitable to multiple offenders (the risk heterogeneity argument), or if it is due to factors related to the initial victimization (the state-dependent argument). In support of the latter view, Polvi et al. (1991: 414) wrote that while characteristics of a dwelling may help determine a first offence against it, 'it is more what it found inside which induces an offender to return'. Discovering whether revictimization results from enduring characteristics of places or from knowledge learned by offenders during their initial offences, is beyond the scope of this present study. The bottom line is that revictimization can be prevented with knowledge of the time and place of its occurrence, regardless of why it occurs.

\section{Preventing Criminal Victimization and Revictimization}

Criminal victimization is more likely to occur, and in fact only possible, when three elements converge in time and space: (1) presence of motivated offenders; (2) presence of suitable targets; and (3) absence of capable guardians (Cohen and Felson 1979: 589). Crime prevention can be achieved effectively when any one of these elements is absent. Thus, if we can identify which potential targets in any given environment are most suitable for victimization, then we can design and implement crime prevention strategies to make them less suitable. This will prevent criminal victimization, or at least lessen the likelihood that a target will be victimized. For example, residences become suitable targets for burglary victimization when they are highly accessible to offenders, especially in conditions of low surveillability to] neighbours and passers-by, and during periods of non-occupancy (Cromwell et al. 1991; Robinson 1994; Wright and Decker 1994). Theoretically, to reduce the probability of victimization, we can reduce accessibility to outsiders, increase surveillability by neighbours and passers-by, and increase periods of resident occupancy. 
At the very least, crime is an event that occurs in time and space (Felson 1983). Therefore, in order to understand and prevent future criminal victimizations and revictimizations, we must be able to locate crime in both space and time. In the words of Polvi et al. (1991:411), 'The more exactly a crime location can be specified in advance, the greater the opportunity for prevention or detection.' Of course, this holds true both for the place and the time of criminal victimization. Polvi et al. (1991: 411) stated it this way: 'To be useful, predictability has to apply in terms of both place (target) and time.'

Since victims suffer from multiple criminal victimizations throughout their life course, victims of yesterday are more likely than non-victims of yesterday to become victims again tomorrow (Johnson et al. 1973). For example, environmental characteristics which make residences more or less susceptible to criminal victimization persist for long periods of time (Polvi et al. 1991: 411). Perhaps the most logical way to identify tomorrow's 'where and when' of criminal victimization is to utilize past criminal data to locate yesterday's 'where and when' of criminal victimization. Given our inability to predict future criminality or victimization accurately (Farrell 1994: 511), this may be our only option. Since repeat criminal victimization is concentrated on few victims (Spelman 1995: 366), crime prevention measures should be focused upon those already victimized (Ellingworth et al. 1995: 365).

This paper is an attempt to identify the 'when' of one type of criminal revictimization. Specifically, the author locates the time period of heightened risk for residential burglary revictimizations relative to initial victimizations. This paper builds on previous attempts of the researcher to locate the 'where' of this type of criminal victimization and revictimization within certain neighbourhoods, on certain streets, and at certain residence types (Robinson 1994; Robinson and Robinson 1995). By continuing this research, the goal is to link the 'where' with the 'when' of burglary revictimization successfully, so that prevention of this type of phenomenon will be much more likely.

\section{Methods}

In order to determine the time period of heightened risk for burglary revictimization of residences in Tallahassee, Florida, computer-generated crime data were obtained from the Tallahassee Police Department's (TPD) 'Crime Analysis Unit'. This crime data contained addresses of residential burglaries reported to TPD, points and methods of 
entry, and dates and estimated times of offences. Since limited data were available, analysis could only be conducted over a three-year period. This is because only police crime data between 1992 and 1994 were stored on the police computers. Furthermore, despite the desire to examine residential burglary data for the entire city, constraints on police time and resources required limiting analysis to a smaller area. Thus, one police zone (zone 7) of TPD's jurisdiction was selected. Zone 7 was selected for several reasons. First, it contains a large proportion of residences which are representative of those who are most likely to be subjected to victimization from residential burglary--the lower class, the working class, the young, etc., meaning that burglary would be likely to exist in this area. Second, zone 7 is characterized by relatively high rates of reported crime, including burglary, which assured having a large enough sample of burglaries to work with.

Of 2,980 separate residential addresses in zone 7, a total of 848 burglaries (including completed burglaries with forcible entry and non-forcible entry, and attempts) were reported to the police between 1992 and 1994. This included 305 burglaries reported to the police in 1992, 337 burglaries in 1993 and 206 burglaries in 1994. This represents an average rate of reported burglary victimization of 94.8 burglaries per 1,000 residences in the area for the years 1992-94. This rate is much higher than the average rate of 59.9 burglaries per 1,000 residences in the United States as a whole (Bureau of justice Statistics 1994). This comparison may underestimate the difference between the rate of burglaries for residences in zone 7 of Tallahassee, Florida (94.8/ 1,000 residences) and the United States as a whole (59.9/1,000 residences). The former represents only burglaries known to the police, while the latter represents crimes from the National Crime Victimization Survey (NCVS), which includes both burglaries known to the police and burglaries not known to the police.

\section{Findings}

Figure 1 displays the time period of heightened risk for burglary revictimization of residences in zone 7 of Tallahassee, Florida. Specifically, it portrays the percentage of revictimization offences which occurred within each week after initial burglary offences were reported to the police from 1992-94. As clearly indicated in Figure 1, the largest share of burglary revictimizations of residences ( 25 per cent) occurred within one week of the initial offences. The general pattern which emerges in Figure 1 is one which shows that as time passes, the risk of burglary revictimization generally diminishes. 


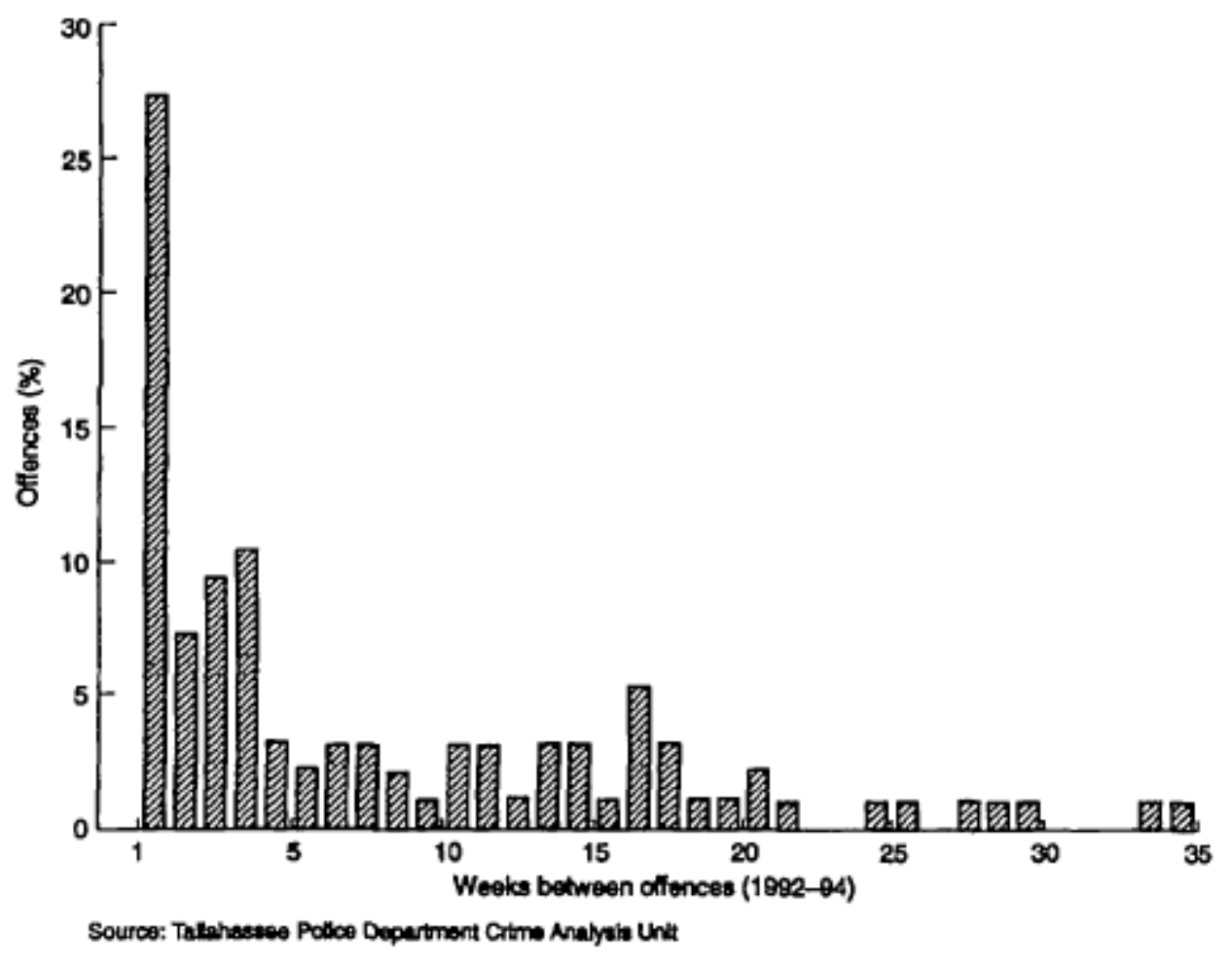

F I G . 1 Number of weeks between original offences and revictimizations

Figure 2 also displays the time period of heightened risk for burglary revictimization of residences in zone 7 of Tallahassee, Florida. Specifically, it portrays the percentage of revictimization offences which occurred within each month after initial burglary offences were reported to the police. As clearly indicated in Figure 2, the majority of burglary revictimizations of residences during this time period (51 per cent) occurred within one month of the initial offences. The general pattern which emerges in Figure 2 is also one which shows that as time passes, the risk of burglary revictimization generally diminishes. In fact, after the fifth month following the initial burglary offence, the risk of burglary revictimization virtually disappears (less than 10 per cent of all reported burglary revictimizations occurred during the sixth through twelfth months after the initial reported offences). 


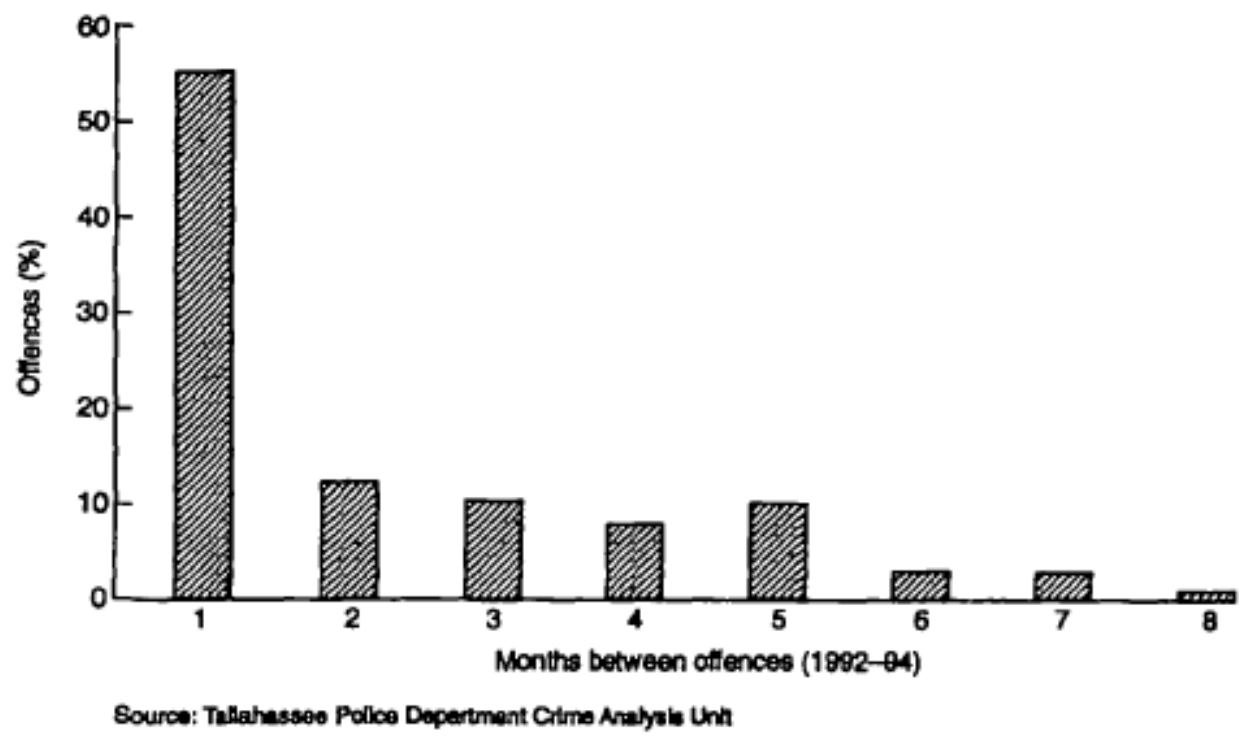

F 1G. 2 Number of months between original offences and revictimization

\section{Conclusions}

This work demonstrates that there is a time period of heightened risk for burglary revictimization immediately after the initial offence. This is consistent with the conclusions of all of the previous literature regarding the time frame of heightened risk for criminal revictimization, which posits that the risk of revictimization is greatest in the period immediately after victimization' (Farrell 1994: 501) and that 'Revictimization is heavily skewed toward the date of the prior victimization' (Farrell 1994: 502). These findings lend further support for the notion that once a criminal victimization has occurred, it is very likely that if revictimization is going to occur, it will be more likely to happen in the short run rather than the long run.

Previous research by the author (Robinson 1994; Robinson and Robinson 1995) has also demonstrated that burglary victimization and revictimization is not highly concentrated in some places, while it is in others. Some streets and some residences have been identified in this area as ones having the highest risk for burglary revictimization. Victimized and non-victimized residences have been differentiated on the basis of their environmental characteristics. For example, burgled residences were 
less able to be subject to surveillance to neighbours and passers-by, more accessible to offenders, and their inhabitants had more regular, predictable patterns of behaviour which left their residences unoccupied for extended period of time. Specific types of residences (e.g., student occupied apartments) had virtually no risk of burglary revictimization in this area, while others had a very high risk (e.g., working class occupied homes). As a result, between the years 1992 and 1994 in zone 7 of Tallahassee, Florida, 29 per cent of all residential burglaries were accounted for by only 1.2 per cent of all residences.

From this continuing research, the picture in regard to the place and time of burglary victimization and revictimization is somewhat clearer. Still, policy and practice are underdeveloped in the area of preventing criminal revictimization. (National Board for Crime Prevention 1994: 4). Much more extensive study is needed to help locate where and when to focus preventive efforts. Regardless of whether or not such study leads to the prevention of revictimization, at least knowing that burglary victimization and revictimization are likely to occur in certain areas and not in others, and that they are more likely to occur at some times rather than others, may improve the effectiveness of law enforcement efforts, because: 'By pointing to the most probable times and places of future offences, repeat victimization also helps identify the times and places where offenders may be found and apprehended' (National Board for Crime Prevention 1994: 2).

\section{Policy Implications}

These findings offer some very clear policy implications. In the words of Polvi et al. (1990: 9): 'To know that a particular person or place is prone to victimization, and when, allows temporary prevention measures to be established.' For example, given the apparent tendency for victims to be revictimized by crimes such as burglary immediately after the initial offence, preventive measures should be taken by citizens and police immediately after a crime has occurred. Thus, immediately after discovering an initial burglary, residents would be wise to expect and prepare for another. This can be achieved by altering the characteristics of the individual residence which may leave it more vulnerable to victimization. For example, bushes which obscure visibility by neighbours and passers-by of entry points could be cut back to make the residence more surveillable. Additionally, inadequate locks on entry points could be replaced with more adequate ones. Temporary or permanent alarms and lighting could be installed to ward off would-be offenders. More importantly, neighbours could be made aware of initial offences so that they will be on the look out for criminality in the immediate future. 
Finally, law enforcement patrols could be directed at areas where criminal victimizations have recently occurred, even if only to increase the probability of apprehending offenders who have committed the revictimizations. Preliminary evidence (Spelman 1995: 38) suggests environmental characteristics which are permanent are more important than temporary characteristics such as increased police patrols for explaining repeat victimization. Therefore, 'long-term problem solving' will be more likely to prevent its occurrence than short-term, quick-fix solutions.

\section{REFERENCES}

Block, R. and Block, C. (1995), 'Space, Place and Crime: Hot Spot Areas and Hot Places of Liquor-Releated Crime', in J. Eck and D. Weisburd, eds., Crime and Place. Monsey, NY: Willow Tree Press.

Buerger, M., Cohn, E. and Petrosino, A. (1995), 'Defining The Hot Spots of Crime: Operationalizing Theoretical Concepts For Field Research', in J. Eck and D. Weisburd, eds., Crime and Place. Monsey, NY: Willow Tree Press.

Bureau of Justice Statistics (1994), Sourcebook of Criminal Justice Statistics. Washington, DC: US Government Printing Office.

Burquest, R., Farrell, G. and Peaske K. (1992), 'Lessons From School', Policing, 8: 14855.

Cohen, L. and Felson, M. (1979), 'Social Change and Crime Rate Trends: A Routine Activity Approach', American Socialogical Review, 44: 588-608.

Cromwell, P., Olson, J. and Avary, D. (1991), Breaking and Entering: An Ethnographic Analysis of Burglary. Newbury Park, CA: Sage. 
Ellingworth, D., Farrell, G. and Pease, K. (1995), 'A Victim is a Victim is a Victim?: Chronic Victimization in Four Sweeps of the British Crime Survey', British Journal of Criminology, 35/3: 360-5.

Farrell, G. (1992). 'Multiple Victimization: Its Extent and Significance', International Review of Victimology, 2/2: 85-102.

-- (1994), 'Why Does Repeat Victimization Occur?', Manchester: University of Manchester, Department of Social Policy and Social Work.

Farrell, G. and Pease K. (1993), Once Bitten, Twice Bitten: Repeat Victimization and its Implications for Crime Prevention, Police Research Group, Crime Prevention Paper 46. London: Home Office.

Farrell, G. Phillips, C. and Pease, K. (1995), 'Like Taking Candy: Why Does Repeat Victimization Occur?', British Journal of Criminology, 35/3: 384-99.

Feinberg, S. (1980), 'Statistical Modeling in the Analysis of Repeated Victimization', in S. Feinberg and A. Reiss, eds., Indicators of Crime and Criminal Justice: Quantitative Studies. Washington, DC: US Department of Justice, Bureau of Justice Statistics.

Felson, M. (1983), 'Ecology of Crime', in S. Kadish, ed., Encyclopedia of Crime and Justice, 665-70.

Forrester, D., Chatterton, M. and Pease, K. (1988a), 'Why it's Best to Lock the Door after the Horse has Bolted', Police Review, 4: 2288-9, November.

--(1988b), The Kirkholt Burglary Prevention Project, Rochdale, Home Office Crime Prevention Unit Paper 13. London: Home Office. 
Forrester, D., Frenz, S., O'Connell, M. and Pease, K. (1990), The Kirkholt Burglary Prevention Project. Phase II, Home Office Crime Prevention Unit Paper 23. London: Home Office.

Genn, H. (1988), 'Multiple Victimization', in M. Maguire and J. Pointing, eds., Victims of Crime. Milton Keynes: Open University Press.

Gottfredson, M. (1984), Victims of Crime: The Dimensions of Risk, Home Office Research Study 81. London: HM Stationery Office.

Hindelang, M., Gottfredson, M. and Garofalo, J. (1978), Victims of Personal Crime: An Empirical Foundation for a Theory of Personal Victimization. Cambridge, MA: Ballinger.

Hope, T. (1982), 'Burglary in Schools: The Prospects for Prevention', Home Office Research and Planning Unit Paper 11. London: HM Stationery Office.

Hough, M. (1986), 'Victims of Violent Crime: Findings from the British Crime Survey', in E. Fattah, ed., Crime Policy to Victim Policy: Reorienting the Justice System. Basingstoke: Macmillan.

Johnson, J., Kerper, H., Hayes, D. and Killenger, G. (1973), The Recidivist Victim: A Descriptive Study, Crime Justice Monograph 4/1. Huntsville, TX: Sam Houston University, Institute of Contemporary Corrections and the Behavioral Sciences.

Jones, T., MacLean, B. and Young, J. (1986), The Islington Crime Survey: Crime Victimization and Policing in Inner-City London. London: Gower.

Mayhew, P., Maung, N. and Mirrlees-Black, C. (1993), The 1992 British Crime Survey. London: HM Stationery Office. 
Miethe, T., Stafford, M. and Long, J. (1987), 'Social Differentiation in Criminal Victimization: A Test of Routine Activities and Lifestyle Theories', American Sociological Review, 52: 184-94.

National Board For Crime Prevention (1994), Wise After the Event: Tackling Repeat Victimisation. London: Home Office.

Nelson, J. (1980), 'Multiple Victimization in American Cities: A Statistical Analysis of Rare Events', American Journal of Sociology, 85/4: 870-91.

Pease K. (1991), 'The Kirkholt Project: Preventing Burglary on a British Public Housing Estate', Security Journal, 2: 73-7.

--(1992), 'The Kirkholt Project: Preventing Burglary on a British Public Housing Estate', in R. Clarke, ed., Situational Crime Prevention: Successful Case Studies. London: Heinemann.

Polvi, N., Looman, T., Humphries, C. and Pease K. (1990), 'Repeat Break-and-Enter Victimisation: Time Course and Crime Prevention Opportunity', Journal of Police Science and Administration, 17/1: 8-11.

-- (1991), 'The Time Course of Repeat Burglary Victimisation', British Journal of Criminology, 31: 411-14.

Reiss, A. (1980), 'Victim Proneness in Repeat Victimization by Type of Crime', in S. Fienberg and A. Reiss, eds., Indicators of Crime and Criminal Justice: Quantitative Studies. Washington, DC: US Department of Justice, Bureau of Justice Statistics.

Robinson, M. (1994), Environmental Characteristics of Burglaries in Private Apartment Complexes Predominantly Occupied by University Students, Zone 7, Tallahassee, 
Florida, 1993. Master's Thesis, School of Criminology and Criminal Justice, Florida State University.

Robinson, M. and Robinson, C. (1995), 'Once Bitten, But Not Twice Bitten: Student Apartment Burglary Cool Spots'. Paper presented to the annual meeting of the Southern Criminal Justice Association, Gatlinburg, Tennessee.

Ross, N. (1994), unpublished paper presented to the National Board for Crime Prevention.

Sampson, A. (1991), Lessons Learnt from a Victim Support Crime Prevention Project, Home Office Crime Prevention Unit Paper 25. London: Home Office.

Sampson, A. and Phillips, C. (1992), Multiple Victimization: Racial Attacks on an East London Estate, Home Office Crime Prevention Unit Paper 36. London: Home Office.

Shapland, J., Wiles, P., Johnson, V. and Leek, M. (1991), Crime at Work: The Victimization of Factories and Employees, unpublished paper. Sheffield: University of Sheffield, Faculty of Law.

Shepherd, J. (1990), 'Violent Crime in Bristol: An Accident and Emergency Department Perspective', British Journal of Criminology, 30: 289-305.

Sherman, L., Gartin, P. and Buerger, M. (1989), 'Hot Spots of Predatory Crime: Routine Activities and the Criminology of Place', Criminology, 27/1:27-55.

Skogan, W. (1990a), 'The National Crime Survey Redesign', Public Opinion Quarterly, 54:256-72. 
-- (1990b), 'Innovations in the Analysis of Crime Surveys'. Paper presented to the Conference on Measurement and Research Design in Criminal Justice, Griffith University, Queensland.

Sparks, R. (1981), 'Multiple Victimization: Evidence, Theory and Future Research', Journal of Criminal Law and Diminology, 72: 762-78.

Sparks, R., Genn, H. and Dodd, D. (1977), Surveying Victim. London: Wiley.

Spelman, W. (1995), 'Once Bitten, Then What? Cross-Sectional and Time-Course Explanations of Repeat Victimization', British Journal of Criminology, 35/3: 366-83.

Tilley, N. (1993), The Prevention of Crime Against Small Businesses: The Safer Cities Experience, Home Office Crime Prevention Unit Paper 45. London: Home Office.

Trickett, A., Osborn, D., Seymour, J. and Pease, K. (1992), 'What is Different About High Crime Areas?', British Journal of Criminology, 32: 250-65.

Wright, R. and Decker, S. (1994), Burglars on the Job: Street Life and Residential Break-Ins. Boston, MA: Northeastern University Press.

Ziegenhagen, E. (1976), 'The Recidivist Victim of Violent Crime', Victimology, 1: 538-50. 